\title{
Isolation and Characterization of Glutamate Synthase Mutants of Azospirillum brasilense
}

\author{
By D. BANI, ${ }^{1}$ C. BARBERIO,$^{1}$ M. BAZZICALUPO, ${ }^{1}$ F. FAVILLI, ${ }^{2}$ \\ E. GALLORI ${ }^{1}$ AND M. POLSINELLI'* \\ Istituto di Anatomia Comparata, Biologia Generale e Genetica ${ }^{1}$ \\ and Istituto di Microbiologia Agraria e Tecnica, ${ }^{2}$ \\ University of Florence, Florence, Italy
}

(Received 6 November 1979; revised 24 January 1980)

\begin{abstract}
Six mutants of Azospirillum brasilense Sp6 unable to fix nitrogen have been isolated and characterized. Analysis of the enzymes involved in nitrogen metabolism has shown that the mutants are deficient in glutamate synthase activity $(\mathrm{asm})$. They also have a low activity of glutamine synthetase and no or very low nitrogenase activity (assayed by acetylene reduction). In addition, the mutants were unable to grow on various sources of combined nitrogen such as nitrate, nitrite, alanine, histidine, adenine and xanthine.
\end{abstract}

\section{INTRODUCTION}

Azospirillum brasilense is a bacterium which is able to fix nitrogen in the free-living state (Becking, 1963). Recently, associative symbiosis of $A$. brasilense with tropical grass and cereal species has been reported (Day et al., 1975; von Bülow \& Döbereiner, 1975; Döbereiner \& Day, 1975; Smith et al., 1976). A number of papers have been published on the taxonomy, physiology and ecology of $A$. brasilense (Burris et al., 1977; Okon et al., 1976a, b, 1977; Krieg, 1977; Matin \& Veldkamp, 1978). Mutants of $A$. brasilense altered in glutamine synthetase [GS; EC 6.3.1.2; L-glutamate:ammonia lyase (ADP-forming)] (Gauthier \& Elmerich, 1977) and nitrate reductase and/or nitrite reductase (Magalhães et al., 1978) have been described, and genetic transformation of $A$. brasilense has recently been reported (Mishra et al., 1979).

According to the model based mainly on studies with Klebsiella pneumoniae, expression of the nitrogenase genes is positively controlled by the enzyme glutamine synthetase (Tubb, 1974; Streicher et al., 1974). Ammonia, in many bacteria, is assimilated by two routes:

(1) via glutamate dehydrogenase [GDH; EC 1.4.1.2; L-glutamate: $\mathrm{NAD}^{+}$oxidoreductase], in the presence of high $\mathrm{NH}_{4}{ }^{+}$concentrations:

$$
\text { 2-Oxoglutarate }+\mathrm{NH}_{3}+\mathrm{NADH} \stackrel{\mathrm{GDH}}{\longrightarrow} \text { Glutamate }+\mathrm{NAD}^{+}
$$

(2) via glutamine synthetase (GS) and glutamate synthase [GOGAT; EC 1.4.1.13; L-glutamate: $\mathrm{NADP}^{+}$oxidoreductase (transaminating)], in $\mathrm{N}_{\mathbf{2}}$-fixing conditions or in limiting $\mathrm{NH}_{4}{ }^{+}$concentrations:

$$
\begin{gathered}
\text { Glutamate }+\mathrm{NH}_{3}+\mathrm{ATP} \underset{\mathrm{Mg}^{2+}}{\stackrel{\mathrm{GS}}{\longrightarrow} \text { Glutamine }+\mathrm{ADP}+\mathrm{P}_{\mathrm{i}}} \\
\text { Glutamine }+ \text { 2-Oxoglutarate }+\mathrm{NADPH} \stackrel{\text { GOGAT }}{\longrightarrow} 2 \text { Glutamate }+\mathrm{NADP}^{+}
\end{gathered}
$$

In the present work we describe six mutants of $A$. brasilense which are unable to fix nitrogen ( Nif $^{-}$) and which are altered in their glutamate synthase activity. The properties of the six mutants resembled those of the asm mutants described in Klebsiella pneumoniae by Nagatani et al. (1971) and Streicher et al. (1972). 


\section{METHODS}

Bacterial strain. Azospirillum brasilense strain Sp6, a prototroph, was used. Its DNA base composition and utilization of carbon and nitrogen sources (Mengoni et al., 1980) are the same as for $A$. brasilense strain Sp7 (Döbereiner \& Day, 1975); both strains belong to group I of Krieg (1977).

Media. Minimal medium (MSP) contained ( $\left.\mathrm{g} \mathrm{l}^{-1}\right): \mathrm{KH}_{2} \mathrm{PO}_{4}, 1 \cdot 5 ; \mathrm{K}_{2} \mathrm{HPO}_{4}, 0.5 ; \mathrm{MgSO}_{4} .7 \mathrm{H}_{2} \mathrm{O}, 0.18$; $\mathrm{NaCl}, 0.1 ; \mathrm{Na}_{2} \mathrm{MoO}_{4}, 0.01 ; \mathrm{CaCl}_{2}, 0.01 ; \mathrm{FeCl}_{2}, 0.01$; sodium succinate, $5 ; \mathrm{NH}_{4} \mathrm{Cl}, 1.3$ (unless stated otherwise); $\mathrm{pH}$ 7. Complete medium (CM) was MSP plus yeast extract $\left(5 \mathrm{~g}^{-1}\right)$ and acid hydrolysed casein $\left(5 \mathrm{~g} \mathrm{l}^{-1}\right)$.

For the nitrogenase assays, the minimal medium was the salt base of Kalininskaja medium (Biggins \& Postgate, 1969) supplemented with sodium succinate $\left(5 \mathrm{~g} \mathrm{l}^{-1}\right)$ and yeast extract $\left(5 \mathrm{mg} \mathrm{l}^{-1}\right)$, and complete medium contained $\left(\mathrm{g} \mathrm{l}^{-1}\right)$ : Bacto-nutrient broth (Difco), $8 ; \mathrm{MgSO}_{4} .7 \mathrm{H}_{2} \mathrm{O}, 0.25 ; \mathrm{KCl}, 1 ; \mathrm{MnCl}_{2}, 0.001$ (Gauthier \& Elmerich, 1977).

All cultures were incubated at $35^{\circ} \mathrm{C}$.

Enzyme assays. Glutamine synthetase: exponential phase bacteria grown in MSP medium were resuspended in $2 \mathrm{~mm}$-Tris/ $\mathrm{HCl}$ buffer, $\mathrm{pH}$ 7, sonicated and centrifuged at $30000 \mathrm{~g}$ for $30 \mathrm{~min}$; the supernatant was used for testing enzyme activity. Biosynthetic activity of GS was determined by the method of Rowe et al. (1970); the relative adenylylation of GS was estimated by the ratio of absorbance values of transferase assays conducted in the presence or absence of $60 \mathrm{mM}-\mathrm{MgCl}_{2}$ (Shapiro \& Stadtman, 1970). Specific activities were expressed as $\mu \mathrm{mol} \gamma$-glutamyl hydroxamate produced $\min ^{-1}(\mathrm{mg} \text { protein })^{-1}$. Glutamate synthase and glutamate dehydrogenase: GDH and GOGAT were assayed as described by Meers et al. (1970) using crude extracts obtained from exponential phase cells grown in MSP medium and resuspended in 2 mM-Tris/ $\mathbf{H C l}$ buffer plus $10 \mathrm{~mm}-2$-mercaptoethanol, $\mathrm{pH}$ 7. Cells were broken by grinding in a mortar with alumina (type 305 , Sigma) and then centrifuged at $6000 \mathrm{~g}$ for $10 \mathrm{~min}$ to remove the alumina; the supernatant was collected and centrifuged at $30000 \mathrm{~g}$ for $30 \mathrm{~min}$. Specific activities were expressed as $\mu \mathrm{mol}$ NADH (GDH) or NADPH (GOGAT) oxidized $\min ^{-1}(\mathrm{mg} \text { protein })^{-1}$. The three enzymes were assayed immediately after extract preparation.

Nitrogenase: nitrogenase activity was assayed by the acetylene reduction method (Postgate, 1972) on whole cells. Exponential phase cells from complete medium (Gauthier \& Elmerich, 1977) were washed and diluted to about $10^{7}$ cells $\mathrm{ml}^{-1}$ in Kalininskaja medium. Portions $(8 \mathrm{ml})$ of this cell suspension were incubated at room temperature in $80 \mathrm{ml}$ test tubes filled with argon and $0.5 \%(\mathrm{v} / \mathrm{v}) \mathrm{O}_{2}$. After $3 \mathrm{~h}$ incubation, $10 \%$ $(\mathrm{v} / \mathrm{v})$ acetylene was injected and the production of ethylene was followed for $3 \mathrm{~h}$. In some experiments cells were kept in Kalininskaja medium plus aspartate $\left(2 \mathrm{~g} \mathrm{l}^{-1}\right)$ for $8 \mathrm{~h}$ under argon and $0.5 \%(\mathrm{v} / \mathrm{v}) \mathrm{O}_{2}$ before injection of acetylene. The ethylene produced was measured with a Packard gas chromatograph with Porapak $\mathrm{T}$ column at $100^{\circ} \mathrm{C}$. Specific activity was expressed as nmol ethylene produced $\mathrm{min}^{-1}$ (mg protein) ${ }^{-1}$.

Protein determination. Proteins were determined by the method of Lowry, using bovine serum albumin (Sigma) as standard.

Utilization of nitrate and nitrite as electron acceptors. Respiratory (dissimilatory) nitrate and nitrite reduction was assayed by estimating anaerobic growth in the presence of $25 \mathrm{~mm}-\mathrm{KNO}_{3}$ or $5 \mathrm{~mm}-\mathrm{KNO}_{2}$ in CM medium. Anaerobic growth was obtained in test tubes $(160 \times 15 \mathrm{~mm})$ filled with $\mathrm{CM}$ medium containing $0.5 \%(\mathrm{w} / \mathrm{v})$ purified agar (Difco) and sealed with rubber stoppers. The appearance of deep colonies was observed after $3 \mathrm{~d}$.

Isolation of mutants. Mutants were obtained from a late-exponential phase culture of $A$. brasilense strain Sp6 treated with $N$-methyl- $N^{\prime}$-nitro- $N$-nitrosoguanidine (Adelberg et al., 1965). Appropriate dilutions of the mutagenized culture were plated on MSP medium containing $25 \mathrm{mM}-\mathrm{NH}_{4} \mathrm{Cl}$; colonies were replicated on to MSP medium without $\mathrm{NH}_{4} \mathrm{Cl}$. After $3 \mathrm{~d}$ incubation at $35^{\circ} \mathrm{C}$, the colonies which did not show growth on the replica plates were picked and purified.

\section{RESULTS}

\section{Utilization of different nitrogen sources by six mutants with a Nif- phenotype}

Six mutants, isolated as described in Methods, were able to grow on MSP containing $\mathrm{NH}_{4} \mathrm{Cl}$ as sole nitrogen source but failed to grow with $\mathrm{N}_{2}$ as sole nitrogen source. One of these mutants (SPF104) gave rise to small colonies on nitrogen-free minimal medium after $4 \mathrm{~d}$ incubation.

In $K$. pneumoniae mutations affecting the ability of the strain to grow on $\mathrm{N}_{2}$ as sole nitrogen source may be either in one of the nif genes (and therefore specific for $\mathrm{N}_{2}$ fixation) or in a gene concerned with general ammonia assimilation. The latter class can be recognized by their inability to utilize a wide range of different nitrogen compounds as sole 
Table 1. Growth of mutants of $A$. brasilense on various compounds as nitrogen sources

\begin{tabular}{|c|c|c|c|c|c|c|c|}
\hline Nitrogen source & $\begin{array}{c}\text { Sp6 } \\
\text { (parental) }\end{array}$ & SPF101 & SPF103 & SPF104 & SPF105 & SPF109 & SPF111 \\
\hline Ammonium chloride & +++ & +++ & +++ & +++ & +++ & +++ & $++t$ \\
\hline $\begin{array}{l}\text { Slutamine } \\
\text { rginine }\end{array}$ & $\begin{array}{l}+++ \\
+++\end{array}$ & $\begin{array}{c}++ \\
++\end{array}$ & & & $\begin{array}{c}+++ \\
++\end{array}$ & $\begin{array}{c}+++ \\
++\end{array}$ & $\begin{array}{c}+++ \\
++\end{array}$ \\
\hline Slutamate & +++ & + & + & ++ & + & + & + \\
\hline sparagine & +++ & + & + & ++ & + & + & + \\
\hline spartate & +++ & + & + & ++ & + & + & + \\
\hline roline & +++ & + & $t$ & ++ & \pm & \pm & \pm \\
\hline Histidine & $+t+$ & - & - & + & - & - & - \\
\hline llanine & +++ & - & - & + & - & - & - \\
\hline Adenine & +++ & - & - & + & - & - & - \\
\hline Kanthine & +++ & - & - & + & - & - & - \\
\hline Nitrate (potassium) & +++ & - & - & + & - & - & - \\
\hline Vitrite (potassium) & +++ & - & - & + & - & - & - \\
\hline $\mathrm{J}_{2} *$ & ++ & - & - & + & - & - & - \\
\hline
\end{tabular}

nitrogen source (Brill, 1975). All the six mutants described here were found to have such a pleiotropic phenotype (Table 1), a phenotype which was similar but not identical to that shown by asm mutants of $K$. pneumoniae (Nagatani et al., 1971).

Owing to the inability of the mutants to assimilate nitrate and nitrite, they were also tested for respiratory utilization of nitrate and nitrite in anaerobic growth experiments, as described in Methods. All the mutants utilized nitrate and nitrite as electron acceptors (results not shown).

\section{Enzymic characterization of the mutants}

Glutamine synthetase, glutamate dehydrogenase and glutamate synthase activities. Extracts were prepared from all six mutants using bacteria grown in minimal medium with two different $\mathrm{NH}_{4}{ }^{+}$concentrations. Five mutants had no detectable GOGAT activity (Table 2), while one (SPF104) retained about $25 \%$ of parental activity; this residual GOGAT activity would explain the ability of mutant SPF104 to give very small colonies in the presence of $\mathrm{N}_{2}$ as sole nitrogen source. The GDH activity of the wild-type strain was similar at both high and low ammonia concentrations. Mutants SPF101, SPF103 and SPF104 had less than $50 \%$ of the parental GDH activity, but mutants SPF105, SPF109 and SPF111 were not affected. In comparison with the parental strain, all six mutants failed to derepress GS when subjected to ammonia limitation.

Nitrogenase activity. Five mutants (SPF101, SPF103, SPF105, SPF109 and SPF111) were unable to reduce acetylene and one (SPF104) showed only about $4 \%$ of parental activity [ 2 nmol ethylene produced $\min ^{-1}\left(\mathrm{mg}\right.$ protein) ${ }^{-1}$ compared with 51 in the parental strain]. The mutants, with the exception of SPF104, did not show ethylene production even after $24 \mathrm{~h}$ incubation with acetylene. The same results were obtained when the mutants were grown in the presence of aspartate as sole nitrogen source (results not shown).

\section{DISCUSSION}

As reported by Tubb (1974), Nagatani et al. (1971) and Okon et al. (1976 b), $\mathrm{N}_{\mathbf{2}}$-fixing bacteria grown in the presence of excess $\mathrm{NH}_{4}{ }^{+}$assimilate ammonia by GDH, and GS is present mainly in the inactive adenylylated form, while bacteria grown in $\mathrm{NH}_{4}{ }^{+}$-limiting conditions or in $\mathrm{NH}_{4}{ }^{+}$-free medium show higher levels of active unadenylylated GS, and GDH synthesis is repressed. The level of GOGAT activity is not necessarily affected by $\mathrm{NH}_{4}{ }^{+}$concentration (Nagatani et al., 1971). 


\section{Table 2. Enzymic activities of extracts from A. brasilense mutants}

GOGAT activities are expressed as $\mu \mathrm{mol}$ NADPH oxidized min $^{-1}$ (mg protein) ${ }^{-1}$, GDH activities as $\mu \mathrm{mol}$ NADH oxidized $\min ^{-1}$ (mg protein $)^{-1}$, and GS activities as $\mu$ mol $\gamma$-glutamyl hydroxamate formed $\min ^{-1}$ (mg protein) $)^{-1}$ for the biosynthetic assay and for the transferase assay.

\begin{tabular}{|c|c|c|c|c|c|c|c|}
\hline \multirow[b]{3}{*}{ Strain } & \multirow{3}{*}{$\begin{array}{l}\mathrm{NH}_{4}+\text { concn } \\
\text { in culture } \\
\text { medium (mM) }\end{array}$} & \multirow[b]{3}{*}{ GOGAT } & \multirow[b]{3}{*}{ GDH } & \multicolumn{4}{|c|}{ GS* } \\
\hline & & & & \multirow{2}{*}{$\begin{array}{c}\text { Biosynthetic } \\
\text { assay } \\
+\mathrm{Mg}^{2+}\end{array}$} & \multicolumn{2}{|c|}{ Transferase assay } & \multirow{2}{*}{$\begin{array}{l}\text { Unadenylylated } \\
\text { form }(\%)\end{array}$} \\
\hline & & & & & $+\mathrm{Mn}^{2+}$ & $+\mathrm{Mn}^{2+}+\mathrm{Mg}^{2+}$ & \\
\hline $\begin{array}{l}\text { Sp6 } \\
\text { (parental) }\end{array}$ & $\begin{array}{l}26 \\
2 \cdot 6\end{array}$ & $\begin{array}{l}0.024 \\
0.039\end{array}$ & $\begin{array}{l}0.139 \\
0.108\end{array}$ & $\begin{array}{l}0.040 \\
1 \cdot 390\end{array}$ & $\begin{array}{r}6 \cdot 535 \\
10 \cdot 335\end{array}$ & $\begin{array}{l}0.385 \\
8.265\end{array}$ & $\begin{array}{r}5 \cdot 9 \\
80 \cdot 0\end{array}$ \\
\hline SPF101 & $\begin{array}{c}26 \\
2 \cdot 6\end{array}$ & $\begin{array}{l}\text { ND } \\
\text { ND }\end{array}$ & $\begin{array}{l}0.019 \\
0.036\end{array}$ & $\begin{array}{l}0.055 \\
0.060\end{array}$ & $\begin{array}{l}8.450 \\
5.000\end{array}$ & $\begin{array}{l}0.562 \\
0.470\end{array}$ & $\begin{array}{l}6 \cdot 6 \\
9 \cdot 4\end{array}$ \\
\hline SPF103 & $\begin{array}{l}26 \\
2 \cdot 6\end{array}$ & $\begin{array}{l}\text { ND } \\
\text { ND }\end{array}$ & $\begin{array}{l}0.058 \\
0.042\end{array}$ & $\begin{array}{l}0.027 \\
0.019\end{array}$ & $\begin{array}{l}3 \cdot 250 \\
0 \cdot 920\end{array}$ & $\begin{array}{l}0 \cdot 165 \\
0 \cdot 180\end{array}$ & $\begin{array}{r}5 \cdot 0 \\
19 \cdot 3\end{array}$ \\
\hline SPF104 & $\begin{array}{l}26 \\
2 \cdot 6\end{array}$ & $\begin{array}{l}0.007 \\
0.009\end{array}$ & $\begin{array}{l}0.046 \\
0.046\end{array}$ & $\begin{array}{l}0.050 \\
0.060\end{array}$ & $\begin{array}{l}0.675 \\
5.450\end{array}$ & $\begin{array}{l}0.067 \\
0.855\end{array}$ & $\begin{array}{l}10 \cdot 0 \\
15 \cdot 7\end{array}$ \\
\hline SPF105 & $\begin{array}{l}26 \\
2 \cdot 6\end{array}$ & $\begin{array}{l}\text { ND } \\
\text { ND }\end{array}$ & $\begin{array}{l}0.096 \\
0.100\end{array}$ & $\begin{array}{l}0.021 \\
0.060\end{array}$ & $\begin{array}{l}2 \cdot 095 \\
2 \cdot 220\end{array}$ & $\begin{array}{l}0.515 \\
0.545\end{array}$ & $\begin{array}{l}24 \cdot 6 \\
24 \cdot 3\end{array}$ \\
\hline SPF109 & $\begin{array}{l}26 \\
2 \cdot 6\end{array}$ & $\begin{array}{l}\text { ND } \\
\text { ND }\end{array}$ & $\begin{array}{l}0 \cdot 180 \\
0 \cdot 138\end{array}$ & $\begin{array}{l}0.011 \\
0.135\end{array}$ & $\begin{array}{l}2 \cdot 195 \\
2 \cdot 890\end{array}$ & $\begin{array}{l}0.105 \\
0.760\end{array}$ & $\begin{array}{r}4 \cdot 8 \\
26 \cdot 0\end{array}$ \\
\hline SPF111 & $\begin{array}{l}26 \\
2 \cdot 6\end{array}$ & $\begin{array}{l}\text { ND } \\
\text { ND }\end{array}$ & $\begin{array}{l}0 \cdot 162 \\
0 \cdot 221\end{array}$ & $\begin{array}{l}0.032 \\
0 \cdot 100\end{array}$ & $\begin{array}{l}1.400 \\
0.600\end{array}$ & $\begin{array}{l}0 \cdot 340 \\
0 \cdot 305\end{array}$ & $\begin{array}{l}24 \cdot 0 \\
50 \cdot 8\end{array}$ \\
\hline
\end{tabular}

$\mathrm{ND}$, Not detectable. $\quad *$ Samples were incubated at $40^{\circ} \mathrm{C}$ for $20 \mathrm{~min}$.

Mutations causing a pleiotropic phenotype with respect to the utilization of a wide range of nitrogen sources have been described in a number of bacteria. They include mutations in the gene for glutamate synthase (GOGAT), referred to as $g l t B$ in Escherichia coli (Pahel et al., 1978) and asm in Klebsiella aerogenes (Brenchley et al., 1973) and K. pneumoniae (Nagatani et al., 1971). Similar phenotypes are found in $g \ln G$ mutants of $E$. coli (Pahel \& Tyler, 1979) and $g \ln R$ mutants of Salmonella typhimurium (Kustu et al., 1979) and also in nit mutants of S. typhimurium (Broach et al., 1976). However, all these mutations except asm (gltB) result in normal levels of GOGAT suggesting that the mutations described here are in the structural gene for glutamate synthase.

These asm mutants of $A$. brasilense failed to derepress GS when grown in conditions of ammonia limitation. A similar effect was observed by Brenchley et al. (1973) in asm mutants of $K$. aerogenes and these authors suggested that the inability to derepress GS was a consequence of GOGAT deficiency. The GOGAT-deficient strains could accumulate glutamine which could inhibit the activity and the deadenylylation of GS. The low level of unadenylylated GS could, in turn, be correlated with the lack of nitrogenase activity in the mutants, if the synthesis of nitrogenase is, in fact, stimulated by unadenylylated GS as suggested by Tubb (1974) and Streicher et al. (1974).

Likewise, as GS has been reported to regulate a large number of enzymes involved in assimilation of poor nitrogen sources (Magasanik, 1977), the low GS activity in the mutants could result in failure to derepress many of these enzymes or failure to derepress certain transport systems as reported for some nitrogen regulatory mutants in S. typhimurium (Govons Kustu et al., 1979). In the $A$. brasilense mutants, lack of assimilation of nitrate and nitrite was not due to failure of these substrates to enter the cell because they were easily utilized as electron acceptors in anaerobic respiration.

Nitrogenase activity was not found in asm mutants of $K$. pneumoniae unless they were grown on aspartate-supplemented medium (Streicher et al., 1972; Shanmugam et al., 1978); at variance with this result, we were unable to detect nitrogenase activity in the $A$. brasilense 
mutants even in the presence of aspartate. However, we cannot exclude that our mutants would express nitrogenase activity in different assay conditions.

Whereas in $K$. aerogenes and $K$. pneumoniae GDH activities are significantly repressed at low concentrations of ammonia (Tyler, 1978), in A. brasilense, as in E. coli and S. typhimurium (Tyler, 1978), the levels of GDH are unaffected by ammonia limitation. GDH activity was not altered in three of the six mutants while the other three mutants, especially SPF101, showed a low GDH activity. It is, however, difficult to explain how GOGAT deficiency could affect GDH activity.

\section{REFERENCES}

Adelberg, E. A., Mandel, M. \& Chein Ching Chen, G. (1965). Optimal conditions for mutagenesis by $N$-methyl- $N^{\prime}$-nitro- $N$-nitrosoguanidine in Escherichia coli K12. Biochemical and Biophysical Research Communications 18, 788-795.

BECKING, J. H. (1963). Fixation of molecular nitrogen by an aerobic Vibrio or Spirillum. Antonie van Leeuwenhoek 29, 326.

Biggins, D. R. \& Postgate, J. R. (1969). Nitrogen fixation by cultures and cell-free extracts of Mycobacterium flavum 301. Journal of General Microbiology 56, 181-193.

Brenchley, J. E., Prival, M. J. \& Magasanik, B. (1973). Regulation of the synthesis of enzymes responsible for glutamate formation in Klebsiella aerogenes. Journal of Biological Chemistry 248, $6122-6128$.

BRILL, W. J. (1975). Regulation and genetics of bacterial nitrogen fixation. Annual Review of Microbiology 29, 109-129.

Broach, J., NeumanN, C. \& Kustu, S. (1976). Mutants strains (nit) of Salmonella typhimurium with a pleiotropic defect in nitrogen metabolism. Journal of Bacteriology 128, 86-98.

voN Bülow, J. F. W. \& DöBEREINER, J. (1975). Potential for nitrogen fixation in maize genotypes in Brazil. Proceedings of the National Academy of Sciences of the United States of America 72, 23892393.

Burris, R. H., Okon, Y. \& Albrecht, S. L. (1977). Physiological studies of Spirillum lipoferum. In Genetic Engineering for Nitrogen Fixation, pp. 445-450. Edited by A. Hollaender. London: Plenum Press.

Day, J. M., Neves, M. P. C. \& Döbereiner, J. (1975). Nitrogenase activity on the roots of tropical grasses. Soil Biology and Biochemistry 7, 107-112.

Döbereiner, J. \& DAY, J. M. (1975). Associative symbiosis in tropical grasses: characterization of microorganisms and dinitrogen fixing sites. In Proceedings of the 1st International Symposium on Nitrogen Fixation, pp. 518-538. Edited by W. E. Newton \& C. J. Nyman. Pullman: Washington State University Press.

GaUthier, D. \& Elmerich, C. (1977). Relationship between glutamine synthetase and nitrogenase in Spirillum lipoferum. FEMS Microbiology Letters 2, 101-104.

Govons Kustu, S., Chadwick McFarland, N., Hui, S. P., Esmon, B. \& Ferro-Luzzi Ames, G. (1979). Nitrogen control in Salmonella typhimurium: co-regulation of synthesis of glutamine synthetase and amino acid transport systems. Journal of Bacteriology 138, 218-234.

KRIEG, N. R. (1977). Taxonomic studies of Spirillum lipoferum. In Genetic Engineering for Nitrogen Fixation, pp. 463-472. Edited by A. Hollaender. London: Plenum Press.

Kustu, S., Burton, D., Garcia, E., McCarter, L. \& McFARLAND, N. (1979). Nitrogen control in Salmonella: regulation by the $g \ln \mathrm{R}$ and $g \ln \mathrm{F}$ gene products. Proceedings of the National Academy of Sciences of the United States of America 76, 45764580.

Magalhães, L. M. S., Neyra, C. A. \& Döbereiner, J. (1978). Nitrate and nitrite reductase negative mutants of $\mathrm{N}_{2}$-fixing Azospirillum spp. Archives of Microbiology 117, 247-252.

Magasanik, B. (1977). Regulation of bacterial nitrogen assimilation by glutamine synthetase. Trends in Biochemical Sciences 2, 9-12.

Matin, A. \& Veldkamp, H. (1978). Physiological basis of the selective advantage of a Spirillum sp. in a carbon-limited environment. Journal of General Microbiology 105, 187-197.

Meers, J. L., Tempest, D. W. \& Brown, C. M. (1970). 'Glutamine(amide): 2-oxoglutarate amino transferase oxido-reductase (NADP)', an enzyme involved in the synthesis of glutamate by some bacteria. Journal of General Microbiology 64, 187-194.

Mengoni, M., Balloni, V., Favilli, F., Materassi, R. \& Polsinelli, M. (1980). Isolamento e preliminare caratterizzazione di mutanti di Spirillum lipoferum. Atti XVIII Congresso Nazionale Società Italiana Microbiologia, 1978 (in the Press).

Mishra, A. K., Roy, P. \& Bhattacharya, S. (1979). Deoxyribonucleic acid-mediated transformation of Spirillum lipoferum. Journal of Bacteriology 137, 1425-1427.

Nagatani, H., Shimizu, M. \& Valentine, R. C. (1971). The mechanism of ammonia assimilation in nitrogen fixing bacteria. Archiv für Mikrobiologie 79, 164-175.

Okon, Y., Albrecht, S. \& Burris, R. H. (1976a). Factors affecting growth and nitrogen fixation of Spirillum lipoferum. Journal of Bacteriology 127, $1248-1254$.

Okon, Y., Albrecht, S. \& Burris, R. H. (1976b). Carbon and ammonia metabolism in Spirillum lipoferum. Journal of Bacteriology 128, 592-597.

Okon, Y., Houchins, J. P., Albrecht, S. L. \& Burris, R. H. (1977). Growth of Spirillum lipoferum at constant partial pressure of oxygen and the properties of its nitrogenase in cell-free 
extracts. Journal of General Microbiology 98, 8793.

PAhel, G. \& Tyler, B. (1979). A new glnA linked regulatory gene for glutamine synthetase in Escherichia coli. Proceedings of the National Academy of Sciences of the United States of America 76, 4544-4548.

Pahel, G., Zelenetz, A. D. \& Tyler, B. M. (1978). glt $\mathrm{B}$ gene and regulation of nitrogen metabolism by glutamine synthetase in Escherichia coli. Journal of Bacteriology 133, 139-148.

Postgate, J. R. (1972). The acetylene reduction test for nitrogen fixation. Methods in Microbiology 6B, 343-365.

Rowe, D. B., Ronzio, R. A., Wellner, V. P. \& MEISTER, A. (1970). Glutamine synthetase (sheep brain). Methods in Enzymology 17A, 900-910.

Shanmugam, K. T., O'Gara, F., Andersen, K. \& VALENTINE, R. C. (1978). Biological nitrogen fixation. Annual Review of Plant Physiology 29, 263-276.

Shapiro, B. M. \& Stadtman, E. R. (1970). Gluta- mine synthetase (Escherichia coli). Methods in Enzymology 17, 910-922.

Smith, R. L., Bouton, J. H., Schank, S. C., QuesenberRy, K. H., Tyler, M. E., Milam, J. R., GASkINS, M. H. \& LiTTEL, R. C. (1976). Nitrogen fixation in grasses inoculated with Spirillum lipoferum. Science 193, 1003-1005.

Streicher, S. L., Gurney, E. G. \& Valentine, R. C. (1972). The nitrogen fixation genes. Nature, London 239, 495-499.

Streicher, S. L., Shanmugam, K. T., Ausubel, F., Morandi, C. \& GoldberG, R. B. (1974). Regulation of nitrogen fixation in Klebsiella pneumoniae: evidence for a role of glutamine synthetase as a regulator for nitrogenase synthesis. Journal of Bacteriology 120, 815-821.

TuBB, R. S. (1974). Glutamine synthetase and ammonium regulation of nitrogenase synthesis in Klebsiella. Nature, London 251, 481-485.

TYLER, B. (1978). Regulation of the assimilation of nitrogen compounds. Annual Review of Biochemistry 47, 1127-1162. 